\title{
Stent use in patients with Marfan syndrome: Not so crazy after all
}

\author{
Ourania Preventza, MD, a,b and Joseph S. Coselli, $\mathrm{MD}^{\mathrm{a}, \mathrm{b}}$
}

\footnotetext{
From the a Division of Cardiothoracic Surgery, Michael E. DeBakey Department of Surgery, Baylor College of Medicine, Houston, Tex; and ${ }^{\mathrm{b}}$ Department of Cardiovascular Surgery, Texas Heart Institute, Houston, Tex. Disclosures: O.P. has served as a consultant for Medtronic and WL Gore \& Associates. J.S.C. has an ownership interest in Vascutek; has received research grants from Bolton Medical, Medtronic, Vascutek, and WL Gore \& Associates; and has served as a consultant for Medtronic and WL Gore \& Associates.

Received for publication Aug 1, 2018; accepted for publication Aug 4, 2018; available ahead of print Sept 11, 2018.

Address for reprints: Ourania Preventza, MD, Department of Cardiovascular Surgery, Texas Heart Institute, 6770 Bertner Ave, Houston, TX 77030 (E-mail: opsmile01@aol.com).

J Thorac Cardiovasc Surg 2019;157:852-3

$0022-5223 / \$ 36.00$

Copyright (c) 2018 by The American Association for Thoracic Surgery

https://doi.org/10.1016/j.jtcvs.2018.08.001
}

Stent use in certain categories of patients remains a controversial topic among various groups of interventionalists. But what is it about patients with a connective tissue disorder, such as Marfan syndrome (MFS), that makes the use of endografts not such a great idea? According to the expert consensus published approximately a decade ago, there are concerns regarding the chronic effects of radial forces on an intrinsically weak aorta and the durability of stent grafts in patients with a connective tissue disorder. ${ }^{1}$ Some reports have suggested that endovascular therapy should be used in patients with a connective tissue disease only when they are not candidates for open surgery and can undergo close, lifetime surveillance. ${ }^{2}$ Additionally, endografts can be used in emergency cases (eg, malperfusion in patients with acute type B aortic dissection) or in cases where both ends of the stent graft can be landed inside a Dacron graft. ${ }^{3}$

In this issue of the Journal, Chen and colleagues ${ }^{4}$ report their promising and provocative results regarding their experience with a large series of patients with MFS who underwent total arch and frozen elephant trunk procedures for acute or chronic type A aortic dissection. The study provides some important findings, the most important being their insightful information regarding remodeling of the distal aorta.

For patients with MFS with acute type A aortic dissection, there is still no consensus regarding the appropriate distal extent of the initial surgery. There is no question that a dilated dissected arch must be replaced. However, in this study population, the maximum preoperative diameter of the arch was $35.8 \pm 11.6 \mathrm{~mm}$ and that of the proximal descending thoracic aorta was $37.3 \pm 11.6 \mathrm{~mm}$. The authors may have come to the same conclusion regarding the fate of the distal aorta if they had selectively treated the patients who had a very dilated dissected arch with frozen elephant trunk and the rest of the patients with an aggressive hemiarch procedure and possibly a stent in the proximal descending thoracic aorta to eliminate the

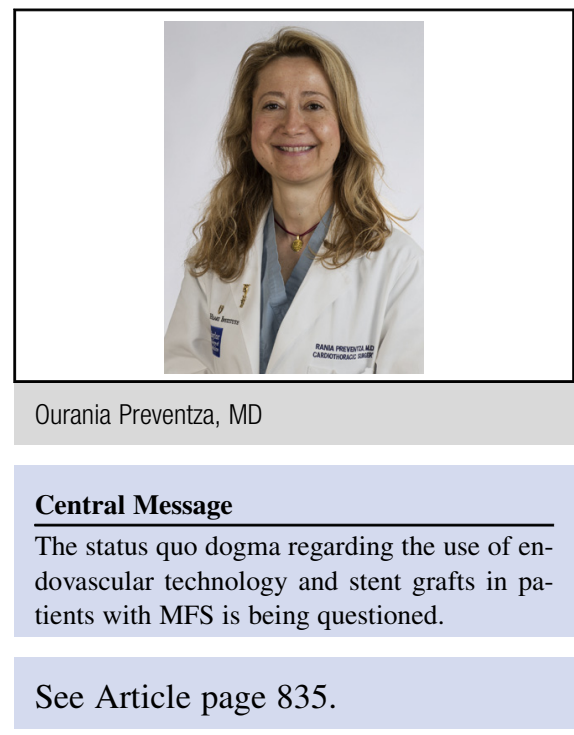

additional morbidity that may be associated with total arch replacement in the setting of acute type A aortic dissection.

Furthermore, the acute $(\mathrm{n}=94)$ and chronic $(\mathrm{n}=78)$ dissections were analyzed together, making it difficult to draw firm conclusions. Nevertheless, the acuity (acute vs chronic) was not a risk factor for distal aortic dilatation, late death, or reoperation. An interesting finding was that the untreated segment of the descending aorta and the diaphragmatic hiatus grew faster in the patients with an acute type A dissection than in those with chronic thoracic aortic dissection. This suggests that the adverse effects the rigid stent has on the remaining untreated aortic segments may be more severe in patients with an acute dissection (who have a friable dissection flap) than in those with a chronic dissection (who have a thicker and less friable dissection flap).

Additionally, the study showed that a partially thrombosed false lumen was not a risk factor for complications, as previously suggested, ${ }^{5}$ and that in most patients, distal aortic dilation occurred within 5 years. This point indicates how important vigorous follow-up of these patients is within the first 5 years after aortic repair and how we must balance the timing of future interventions to avoid rupture. In addition, this study raises the question of whether the use of different endografts with possibly different radial force properties would produce different results.

Overall, the article by Chen and colleagues ${ }^{4}$ is an important contribution to the literature. 


\section{References}

1. Svensson LG, Kouchoukos NT, Miller DC, Bavaria JE, Coselli JS, Curi MA, et al. Expert consensus document on the treatment of descending thoracic aortic disease using endovascular stent-grafts. Ann Thorac Surg. 2008;85: S1-41.

2. Clough RE, Martin-Gonzalez T, Van Calster K, Hertault A, Spear R, Azzaoui R, et al. Endovascular repair of thoracoabdominal and arch aneurysms in patients with connective tissue disease using branched and fenestrated devices. Ann Vasc Surg. 2017;44:158-63.

3. Preventza O, Mohammed S, Cheong BY, Gonzalez L, Ouzounian M, Livesay JJ, et al. Endovascular therapy in patients with genetically triggered thoracic aortic disease: applications and short- and mid-term outcomes. Eur J Cardiothorac Surg. 2014;46:248-53.

4. Chen Y, Ma W-G, Zhi A-H, Lu L, Zheng J, Zhang W, et al. Fate of distal aorta after frozen elephant trunk and total arch replacement for type A aortic dissection in Marfan syndrome. J Thorac Cardiovasc Surg. 2019;157:835-49.

5. Reutersberg B, Trenner M, Haller B, Geisbusch S, Reeps C, Eckstein HH. The incidence of delayed complications in acute type B aortic dissections is underestimated. J Vasc Surg. 2018;68:356-63. 